\title{
酸化クロムーアルミナ触媒による イソペンタンの接触脱水素反応*
}

\author{
瀬 川 幸 一**, 石 井 直 治 郎**
}

Catalytic Dehydrogenation of Isopentane on $\mathrm{Al}_{2} \mathrm{O}_{3}-\mathrm{Cr}_{2} \mathrm{O}_{3}$ Catalyst*

by Koh-ichi Segawa** and Naojiro Ishii**

\begin{abstract}
Summary : As a basic research for the study of the dehydrogenation of paraffins, the catalytic dehydrogenation of isopentane has been studied on $\mathrm{Al}_{2} \mathrm{O}_{3}-\mathrm{Cr}_{2} \mathrm{O}_{3}$ catalyst. Catalysts were prepared by impregnation of $\mathrm{CrO}_{3}$ on $\mathrm{Al}_{2} \mathrm{O}_{3}$, and were reduced with hydrogen at $550^{\circ} \mathrm{C}$. Nitrogen was used as a diluent. Reaction conditions were as follows; $P_{i}=0.08 \sim 0.13 \mathrm{~atm}, t=460 \sim 540^{\circ} \mathrm{C}, W / F=11.4 \sim 56.7 \mathrm{hr} \cdot \mathrm{g}-\mathrm{cat} / \mathrm{mol}-\mathrm{feed}$. Under these conditions, isoamylenes $(3 \mathrm{M} 1 \mathrm{~B}, 2 \mathrm{M} 1 \mathrm{~B}, 2 \mathrm{M} 2 \mathrm{~B})$ and isoprene were formed as dehydrogenation products, and dehydroisomerization $(1-P+2-P)$ and cracking $\left(\mathrm{C}_{1} \sim \mathrm{C}_{4}\right)$ took place to a small extent as the side reactions. The composition of isoamylenes did not depend on the type of catalyst, $P_{i}$ and $W / F$, but showed an isomerization equilibrium. As the contents of $\mathrm{Cr}_{2} \mathrm{O}_{3}$ increased, the dehydrogenation activity increased, and lowered with the addition of hydrogen, isoprene or pyridine in the reaction system. The initial activity of the oxidized catalyst was higher than that of the reduced catalyst. The effect of addition of alkali metal oxide or alkaline earth metal oxide to $\mathrm{Al}_{2} \mathrm{O}_{3}-\mathrm{Cr}_{2} \mathrm{O}_{3}$ catalyst was also investigated. The addition of such a metal oxide reduced the acidity $\left(p K_{a} \leqq+3.3\right)$. It was suggested that the yield of isoprene correlates with the ionic radius of the added metal oxide. The order of the reactivity of isopentane, $2 \mathrm{M} 1 \mathrm{~B}$ and $2 \mathrm{M} 2 \mathrm{~B}$ as a feedstock under the same conditions were as follows; $2 \mathrm{M} 1 \mathrm{~B}>2 \mathrm{M} 2 \mathrm{~B}>$ Isopentane.
\end{abstract}

\section{1 緒言}

酸化クロムーアルミナ系触媒の構造および性啠と各種の反応 の活性に関する研究は多数ありおもに $n$-プタン"，メチルシ クロヘキサン2)など骨格構造の変化しない脱水素反応， $n$ 一个キ サン゙，n-ヘプタン4などの脱水素環化反応がある。そのほか脱 アルキル化反応, 不均化反応にも活性があるといわれている。
領域での，各種反応条件の影響，触媒の酸化クロム含有量の影 帮、アルカリ金属扩よびアルカリ土類金属酸化物の添加効果, 触媒の酸性度などを調べ，これらの結果から酸化クロムーアル ミナ触媒のイソペンタンに対する作用機搆について若干の考察 行なったので報告する。

\section{2 実験および方法}

しかし酸化クロムの性質とインペンタンの 脱水素反応の活性とむすびつけた研究は少な く，その酸性質やアルカリ金属酸化物の添加 効果などの詳細な検討はなされていない。ま

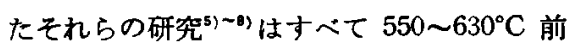
後の比較的高い温度で反応を行ない, かなり 化率の高い反応条件の結果を報告してい る。すなわち転化率が高いため， 2 次的に分 解, 骨格異性化脱水素, 炭素析出などの副反 态も盛んに起こり，触媒の定常活性を保ちに くく, 主反応の脱水素反応と混同し, 反応機 構などの考察には必ずしも適当でない。 本研究に拈いては，それらの点を考慮に入 れて，副反応がほとんど起こらない低転化率

* 昭和 47 年 5 月 25 日受理 この報文を「パラフィン系炭化水素の脱水素 反応㰾する研究 (第 1 報)」とする。

** 上智大学理工学部化学科 (東京都千代田区紀 尾井町) Department of Chemistry, Faculty of Science and Technology, Sophia University (Kioi-cho, Chiyoda-ku, Tokyo)

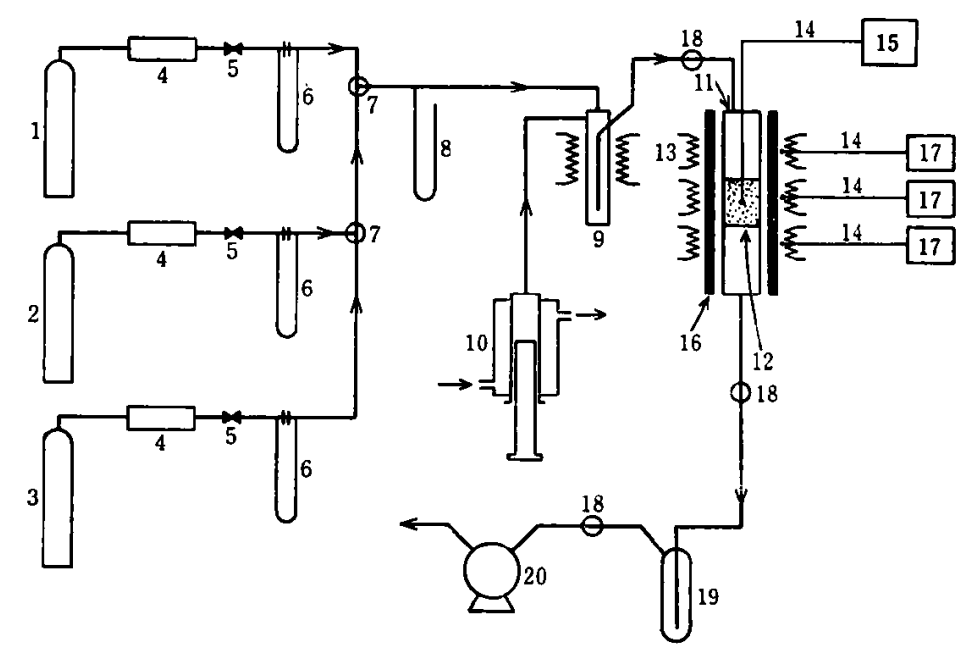

1 Nitrogen bomb 5 Needle valve 9 Preheater

13 Electric furnace 17 Temperature controller
2 Hydrogen bomb 3 Oxygen bomb 4 Silica gel tube 6 Flow meter 7 3-way cock 8 Manometer 10 Feeder 11 Reactor tube 12 Catalyst bed 14 Thermocouple 15 Thermometer 16 Stainless steel block 18 Sampling Cell 19 Trap 20 Wet gas meter

Fig. 1 Experimental Apparatus 


\section{1 実験壇置およひ操作}

反応は気相反応であり，通常の流通式 固定床反応装固を 用 い, その概略図を Fig. 1 に示す。

反応管 (11) は内径 $17 \mathrm{~mm}$, 長さ $350 \mathrm{~mm}$ の透明石英管で， 中心部綐軸方向に外径 $3.5 \mathrm{~mm}$ の熱電対そう入管が設けてあ る。反応妒 (13) は上下三等分され，ステンレスブロック(16) を介してそれぞれ自動温度調節を行ない，広い範囲で均一な温 度分布を示すようにしてある。試料注入ポンプ (10) は原料イ ソペンタンの沸点が約 $28^{\circ} \mathrm{C}$ と低いため蒸発損失を防ぐため常 時 $5^{\circ} \mathrm{C}$ に保たれている。触媒は12〜24メッシュにふるい別け したものを用い， $350^{\circ} \mathrm{C} ， 3$ 時閂予備的に僄元した触媒を所定 量（1〜10 g)とり，温度分布をさらに均一にするために石英千 ップ（8〜12 メッシュ）で希釈混合し反応管に充てんした。反 応に先立ち $550^{\circ} \mathrm{C} 、 3$ 時間で水素遥元を行ないただちに窒素ガ スに切り替え, 所定の窒素流速と反応温度に設定後 3 時間たっ

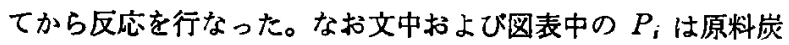
化水素初分圧であり，タイムファクターは $W / F$ で示した。

\section{2 反瓜試薬}

試料油イソペンタン, 2-メチルー1-ブテン (以下 2 M I B), 2-メチル-2-ブテン (以下 $2 \mathrm{M} 2 \mathrm{~B}$ )，イソプレンは市販特級品 を用いた。イソペンタンについてはモレキュラーシープ $5 \mathrm{~A} に$ て微量の n-ペンタンおよび水を除去して使用した。2 M 1 B, $2 \mathrm{M} 2 \mathrm{~B}$, イソプレンは金属ナトリウムにて脱水後そのまま用い た。

空素, 水素, 酸素ガスは市販ボンベ詰めの物を，モレキュラ ーシーブ $4 \mathrm{~A}$ 管を通して使用した。

\section{3 触媒の調製}

担体として用いたアルミナは市販の活性アルミナ（日揮化学 社製，N-611）であり，ナへて含浸法により触媒を調製した。 すなわち 12〜24 メッシュに破砕した活性アルミナを所定量容 器にとり，40ㄷ の恒温そう中で 1 時間脱気した。含浸液の濃 度は酸化ク口ムの担持量によって異なるが，8２0 wtপ6 の無 水ク口ム酸水溶液を脱気後たたちに滴下し, 恒温そう中 $40^{\circ} \mathrm{C}$, 24 時間で含浸させた。含浸後, 余分の無水ク口ム酸水溶液を, 万過, 分離し, $110^{\circ} \mathrm{C}, 24$ 時間乾燥させ, さらに $350^{\circ} \mathrm{C}, 3$ 時 間で水素僄元を行なった。1段の含浸で得られる酸化クロムの 担持量よりさらに高い担持量の触媒を得るには, 含浸から水素 還元までの一連の操作をくり返した。

調製した酸化クロムーアルミナ触媒のクロム担持量の定量9 には，触媒をアルミナルツボ中で過酸化ナトリウムで溶融し， 硫酸酸性にした後, さらに過硫酸アンモニウム水溶液で酸化 し，硫酸第一鉄アンモニウムと過マンガン酸カリウムによる酸 化還元滴定により求めた。

なお使用したアルミナはX線回折で調べたところ，三つのブ ロードのピークが認められ，それぞれのd 值は 1.98，1.40， 2.39 であり，これから使用したアルミナはほぼ 7 体であると 考えられる。

酸化クロムーアルミナ触媒にアルカリ金属およびアルカリ土 類金属酸化物を添加する場合は，すべてそれらの硝酸塩水溶液 を用い，酸化クロムーアルミナ触媒を恒温そう中で脱気後，所 定量の水溶液を滴下し， 24 時間で含浸させ，蒸発乾燥後，お のおのの硝酸塩の分解点以上の温度で 24 時間空気中で焼成を
行なった。

調製した触媒は粉末（100〜150 メッシュ）にし，錠刘成型 (20 $\left.、 2 \mathrm{~mm}, 2,300 \mathrm{~kg} / \mathrm{cm}^{2}\right)$ した後さらに破砕し，12 24メッ シニにそろえたものを反忘に用いた。

\section{4 反応生成物の分析}

イソペンタンおよび反応生成物の分析は，ガスクロマトグラ フ法（柳本製 GCG-500T, TCD）により行ない,キャリアー ガスは水素を用いた。分析条件を Table 1 に示す。定量法に ついてはピーク面積を半值幅法により求め，水素キャリアーガ スを使用したときの相対感度 ${ }^{(0)}$ より補正值を算出してピーク面 積にかけてモル比とした。

Table 1 Analytical Conditions of Gas Chromatography

\begin{tabular}{|c|c|c|c|}
\hline Column & $\begin{array}{c}\text { DMS*/ } \\
\text { Chromosorb }\end{array}$ & $T C P * * / C-22$ & $\begin{array}{l}\text { Active } \\
\text { Alumina }\end{array}$ \\
\hline $\begin{array}{l}\text { Column Length } \\
\qquad(\mathrm{m}) \times \phi(\mathrm{mm})\end{array}$ & $6 \therefore 4$ & & \\
\hline Column Temp. $\quad\left({ }^{\circ} \mathrm{C}\right)$ & 10 & room temp. & room temp. \\
\hline $\begin{array}{l}\text { Carrier gas Rate } \\
\text { (m } l / \mathrm{min})\end{array}$ & 25 & & 30 \\
\hline Subjects of Analysis*** & $\begin{array}{l}C_{3}, C_{4}, C_{3}, \\
C_{3}=, \\
C_{4}=, \\
C_{3}=\end{array}$ & $\mathrm{C}_{4}=\mathrm{C}_{s}$ & $\begin{array}{l}\mathrm{C}_{1}, \mathrm{C}_{2}, \\
\mathrm{C}_{2}=, \mathrm{C}_{3}\end{array}$ \\
\hline
\end{tabular}

\footnotetext{
* Dimethyl sulfolane

** Tricresyl phosphate

*** $\mathrm{C}_{n}$ : paraffin, $\mathrm{C}_{n}=$ : olefin
}

\section{5 触媒の酸性度の測定}

酸性度の測定には $n$-ブチルアミン滴定法 ${ }^{11), 12}$ によったが， 酸化クロムーアルミナ系触媒はこれが還元された時は浱い緑青 色であり，酸素あるいは空気で高温酸化された場合は茶かっ色 であるために，直接アミンの滴定終点を確認することはできな い。よって酸点の呈色がはっきりと確認できるシリカーアルミ 十触媒 (日揮化学社製, N-631, 酸性度 $00.8 \mathrm{~m} \mathrm{~mol} / \mathrm{g}, p K_{a} \leqq$ +3.3）を適当量，すなわち測定する酸化クロムーアルミナ系触 媒の重量の約 $1 / 4 \sim 1 / 3$ を加えて滴定し，シリカーアルミナ触媒 の酸性の呈色が消えた点を終点とした。使用した指示薬は $p-$ ジメチルアミノアジベンゼン $\left(p K_{a}=+3.3\right)$ である。 $n$-ブチ ルアミン滴定法でこの種の触媒の酸性度を測定するのはその精 度において疑問視されているむきすあるが，本研究においては 求めた酸性度は五つの測定値の平均值であり，その平均值に対 して 10〜13\%（90\% 信頼限界）の精度であったので次善の 方法として採用した。測定に先立ち酸化クロムーアルミナ系触 媒を粉末にし，子るい分けし，100メッシュ下粒分を磁製ボー トに入れ，管状炉中て $500^{\circ} \mathrm{C} ， 3$ 時間水素摆元を行ない，加熱 終了後室温まで水素気流中で邻却し，ただちにデシケーター中 に密せん保管したものを測定に用いた。

触媒の酸性度の算出は次式に従った。

$$
\begin{aligned}
& A=\frac{1}{W}\left(\frac{f V}{10}-a w\right) \\
& \text { ただし， } \\
& A: \text { 試料（酸化クロムーアルミナ）の酸性度 }(\mathrm{m} \mathrm{mol} / \mathrm{g} \text { ) } \\
& \mathrm{W}: \text { 試料（酸化クロムーアルミナ）の重量 }(\mathrm{g}) \\
& V: N / 10 n \text {-ブチルアミン・ベンゼン溶液滴下量 }(\mathrm{m} l) \\
& f: N / 10 n \text {-ブチルアミン・ベンゼン溶液のフォクター } \\
& a: \text { 加えたシリカーアルミナの酸性度 }(\mathrm{m} \mathrm{mol} / \mathrm{g} \text { ) } \\
& w \text { : 加えたシリカーアルミナの重量（g） }
\end{aligned}
$$




\section{3 結果と考察}

\section{1 蝶活性の経時変化}

イソペンタンおよびイソアミレンの脱水素反応は本梊的には 吸熱反応であり，定常な活性を示すまでに反応床の温度低下が 予想されるが，本実験においては，反応床が比較的微少なため 触媒層の温度低下はほとんど認められなかった。各反応温度に おける反応経過時間の影響を Fig. 2 に示す。比較的低い反応 温度においては良好な定常活性を示すが， $575^{\circ} \mathrm{C}$ 以上反応温度 が高くなると反応経過時間にしたがって活性が低下する。

またクロムとアルミの原子比で約 4〜15 atom $\%$ と変化させ

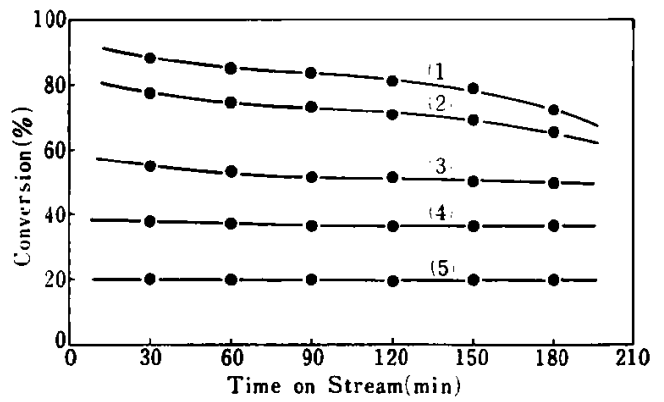

Reaction temperature $\left({ }^{\circ} \mathrm{C}\right)$; (1) $: 625,(2): 600,(3): 575$, (4) : $550,(5): 525$

Reaction conditions; $P_{i}=0.1 \mathrm{~atm}, W / F=56.7 \mathrm{hr} \cdot \mathrm{g}$-cat $/ \mathrm{mol}$ feed, $\mathrm{Cr}: 9.18$ atom\%

Fig. 2 Effect of Reaction Temperature

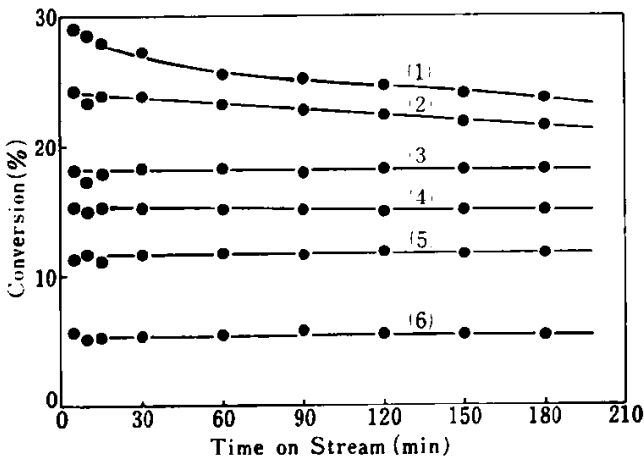

Cr Content (atom\%); (1):15.3, (2):13.1, (3):8.5, (4) : 6.6, (5) :4.4, (6) :3.1

Reaction conditions; $\quad P_{t}=0.1 \mathrm{~atm}, t=520^{\circ} \mathrm{C}$, $W / F=56.7 \mathrm{hr} \cdot \mathrm{g}-\mathrm{cat} / \mathrm{mol}-$ feed

Fig. 3 Effect of $\mathrm{Cr}$ Content

Table 2 Product Distribution on Conversion and Yield $\left(\mathrm{Cr}_{\mathrm{r}}: 9.18\right.$ atomo

\begin{tabular}{|c|c|c|c|c|c|c|c|c|c|c|c|}
\hline \multicolumn{2}{|c|}{ Ex. No. } & 459 & 460 & 477 & 475 & 410 & 511 & 516 & 456 & 451 & 446 \\
\hline$P_{t}$ & (atm) & 0.10 & 0.10 & 0.10 & 0.10 & 0.10 & 0.10 & 0.10 & 0.08 & 0.10 & 0.13 \\
\hline$P_{\mathrm{H}_{2}}$ & (atm) & 0.00 & 0.00 & 0.00 & 0.00 & 0.90 & 0.00 & 0.05 & 0.00 & 0.00 & 0.00 \\
\hline$P_{\mathrm{N}_{2}}$ & (atm) & 0.90 & 0.90 & 0.90 & 0.90 & 0.00 & 0.90 & 0.85 & 0.92 & 0.90 & 0.87 \\
\hline$t$ & $\left({ }^{\circ} \mathrm{C}\right)$ & 480 & 540 & 520 & 520 & 520 & 500 & 500 & 520 & 520 & 520 \\
\hline \multicolumn{2}{|c|}{$W / F^{*}$} & 34.2 & 34.2 & 45.1 & 11.3 & 45.4 & 22.7 & 22.7 & 34.2 & 34.2 & 34.2 \\
\hline Conversion & $(\%)$ & 2.49 & 11.10 & 13.38 & 4.38 & 8.55 & 6.49 & 5.61 & 9.25 & 8.68 & 7.60 \\
\hline $\mathrm{C}_{1} \sim \mathrm{C}_{4}$ & $(\%)$ & - & 0.52 & 0.50 & - & 0.21 & 0.08 & 0.08 & 0.29 & 0.20 & 0.35 \\
\hline$i-\mathrm{C}_{5} \mathrm{H}_{10}$ & $(\%)$ & 2.10 & 7.04 & 9.16 & 3.37 & 8.14 & 5.07 & 5.06 & 6.40 & 6.14 & 6.12 \\
\hline$i-\mathrm{C}_{5} \mathrm{H}_{8}$ & $(\%)$ & 0.39 & 3.38 & 3.56 & 1.01 & - & 1.34 & 0.47 & 2.50 & 2.30 & 1.08 \\
\hline $1-P+2-P$ & $(\%)$ & - & 0.16 & 0.16 & - & 0.20 & - & - & 0.06 & 0.04 & 0.05 \\
\hline \multicolumn{2}{|c|}{$i-\mathrm{C}_{5} \mathrm{H}_{8} / i-\mathrm{C}_{5} \mathrm{H}_{20}$} & 0.19 & 0.48 & 0.39 & 0.30 & - & 0.26 & 0.09 & 0.39 & 0.37 & 0.18 \\
\hline
\end{tabular}

* hr.g-cat/mol-feed
た触媒の活性経時変化を Fig. 3 に示す。酸化クロム含量が多 くなるにしたがってイソペンタン添加率が上㫒するが, 酸化ク 口么含量の多い触媒は反态経過時間にしたがって活性が低下す る傾向にある。活性低下のおもな原因は触媒表面にコークが沈 着するためと考えられるが，反応温度 $550^{\circ} \mathrm{C}$ 以下でクロム含量 12 atomg 程度までの触媒を用いた場合，コーク生成による活 性低下はほとんどないものと考えられる。

\section{2 反応生成物分布}

クロム含量 9.18 atom $\%$ の触媒により，インペンタンの按 触脱水素反応を種々の反応条件で行ないその代表的な結果を Table 2 に示す。

反応はおもに 3 種類に大別できる。すなわち主反応である脱 水素反応と骨格異性化を伴5脱水素反応，および分解反応であ る。脱水素反忘の生成物は 3-メチルー1-ブテン (以下 $3 \mathrm{M} 1 \mathrm{~B}$ ), 2M1 B，2M 2 B 掞よびインプレンである。骨格異性化脱水素 反応の生成物は 1-ペンテン, trans-2-ペンテン, cis-2-ペンテ ンである。分解反応は括もにメタンとインブテンが生成し，反 応温度 $540^{\circ} \mathrm{C}$ 以下では両者ともほぼ等 モル生成し, その他反 応率が十数 \% 以上大きくなるとエタン, エチレン, プロピレ ンなども生成する。

これらの反応条件下で反応を行なった場合脱水素生成物の収 率の序列は

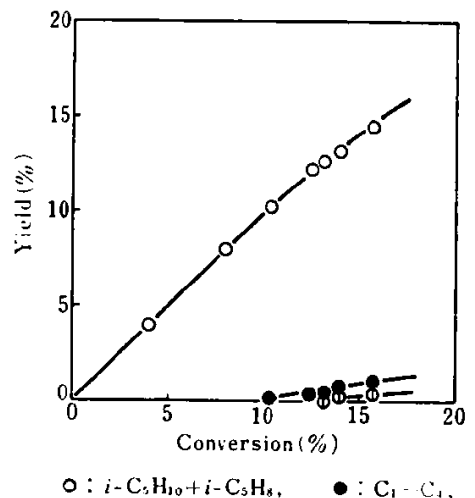

$$
\text { D : } 1-\mathrm{P}+2-\mathrm{P}
$$

Reaction conditions;

$P_{i}=0.1 \mathrm{~atm}, t=520^{\circ} \mathrm{C}, W / F=11.3$

$\sim 56.7 \mathrm{hr} \cdot \mathrm{g}$-cat $/ \mathrm{mol}-$ feed, $\mathrm{Cr}: 9.18$ atom\%

Fig. 4 The Relation of Conversion and Yield and the Distribution of Products

$3 \mathrm{M} 1 \mathrm{~B}$

となるが, 516 番の実 験のと㧍り，反応系中 に水素を添加するとイ ソプレンの生成が極度 に阻害される。このこ とは水素の存在によっ て脱水素の逆反応が促 進されてイソプレンが 生成しにくくしている か, 水秦上炭化水素の 競争吸着が起こり水素 の吸着力が強いためと 考えられる。

脱水素 $\left(i-\mathrm{C}_{5} \mathrm{H}_{10}+\right.$ $\left.i-\mathrm{C}_{5} \mathrm{H}_{8}\right)$, 分解 $\left(\mathrm{C}_{1} \sim\right.$ $\mathrm{C}_{4}$ ), 骨格 異性化脱水 素 $(1-P+2-P)$ の 反応生成物の分布を， 接触時間をパラメーター として転化率と収率との 関係で示すと Fig. 4 の よ5になり，反応率が高 くなるにしたがって脱水 素反応のほ加に分解，骨 格異性化脱水素反応が認 められ, これら3 種類の 反応の生成量の量的な関 係は次のようになる。 


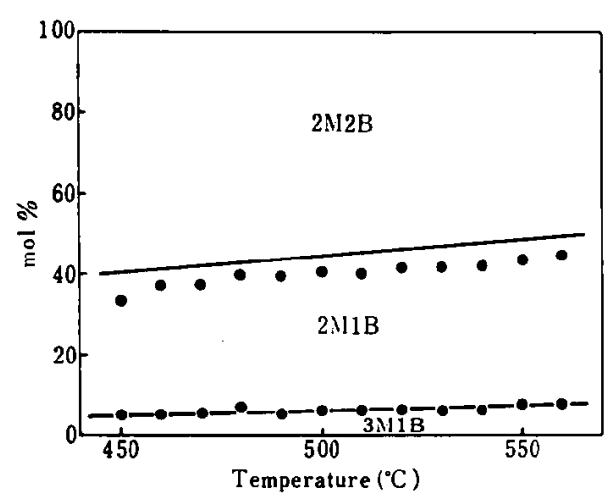

Reaction conditions ;

$P_{t}=0.1 \mathrm{~atm}, W / F=22.7 \mathrm{hr} \cdot \mathrm{g}-\mathrm{cat} / \mathrm{mol}$-feed, Cr $: 9.18$ atom\%

Fig. 5 Composition of Isoamylenes

次に脱水素反応の主生成物である $3 \mathrm{M} 1 \mathrm{~B}$, 2M1 B, 2 M 2 B の生成比を調べたところ, そ の租成比は接触時問, 希勫物犋, 触媒には依存 せず一定となり，反応温度にのみ依存した。各 反応温度における生成したイソアミレンの組成比は反応温度に よりわずかずつ変化し，3M1B と $2 \mathrm{M} 1 \mathrm{~B}$ の組成比は反応温 度が上がるにしたがって上䄯し，2Ｍ２Ｂは減少する。Fig. 5 にそのイソアミレン分布を示したが, 図中の実線はインアミレ ン同志の分子内二重結合異性化反応を想定してイソアミレンそ れぞれの Heat of formation $\left(\Delta H_{f}{ }^{0}\right)^{0} と$ Free energy func. tion $\left(F^{0}-H_{0}{ }^{0}\right) / T^{11)}$ より異性化平衡組成を計算した值である。

また反応系に $2 \mathrm{M} 1 \mathrm{~B}$ を添加して反応を行なった場合も反応 管出口のイソアミレン組成比は $2 \mathrm{M} 1 \mathrm{~B}$ の添加量にかかわらす 一定となり，その結果を Fig. 6 に示す。

以上よりインアミレン同志の分子内二重結合異性化速度は脱 水素反応に比較して非常に速く, その組成比は熱平衡値に近い 值をとると考えられる。

\section{3 酸化クロム含量の影響}

酸化クロムーアルミナ触媒の酸化クロムの含量は触媒の活性

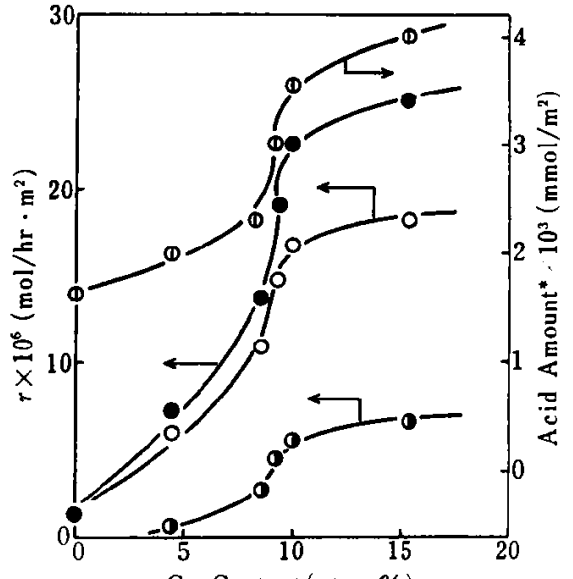

Cr Content (atom \%)

$\bullet$ : Isopentane decomposition

0 : Isoamylenes formation

- : Isoprene formation

(1: Acid amount

Reaction conditions; $P_{1}=0.1 \mathrm{~atm}, t=500^{\circ} \mathrm{C}$ $W / F=22.7 \mathrm{hr} \cdot \mathrm{g}$-cat $/ \mathrm{mol}$-feed $\quad * p K_{a} \leqq+3.3$

Fig. 7 Effect of $\mathrm{Cr}$ Content
に大きな影響を与える。Fig. 7 に BET 法により求めた各クロム含量の触媒の表 面積より単位表面積あたりに換算した酸 性度とイソペンタン消失速度 $r_{A}$,イソ アミレン生成速度 $r_{B}$,イソプレン生成 速度 $r_{C}$ との関係を示す。クロム含量が 増すにしたがって $r_{A}, r_{B}, r_{C}$ も増加し 酸性度と比較的良い対応関係を示寸。し かしクロム含量 10 atom\%以上の触媒は それぞれの上昇が多少頭打ちの傾向にあ る。この反応においては接触時間 (W) $F)$ とインペンタン変化率 $\ltimes$ より求め た $-\log (1-\alpha)$ との関係が 直線になる こと ${ }^{(2)}$ から反応速度はイソペンタンに関 して1次で整理でき, それより各クロム 含量の見かけの活性化エネルギーを求め ると Fig.8のようになり,クロム含量が 增すにしたがって $26.4 \sim 18.5 \mathrm{kcal} / \mathrm{mol}$ と変化したが,やはり高いクロム含量で は変化がゆるやかにな

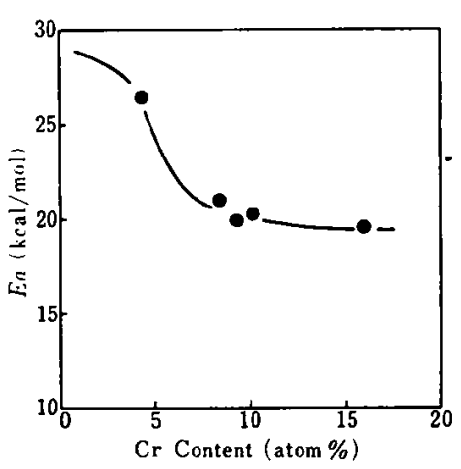

Reaction conditions; $P_{i}=0.1 \mathrm{~atm}, t=460 \sim 500^{\circ} \mathrm{C}$, $W / F=22.7 \mathrm{hr} \cdot \mathrm{g}$-cat $/ \mathrm{mol}$-feed

Fig. $8 \mathrm{Cr}$ Content vs. Apparent Activation Energy $\left(E_{a}\right)$
り，ある值に近つく傾 向にある。

以上の結果から酸化 クロムの性翼が影著に 琶められるのはクロム 含量 10 atom $\%$ 前後ま でであり，それ以上酸 化ク口ムの量を增加さ せても，触媒活性も酸 性度も大幅には增大し ないよ5である。これ はクロム含量が增加す ると酸化クロムがアル ミ十表面に均一に分散
しにくくなり，層となってアルミナ表面に担持されるためでは ないかと考えられる。

3.4 ピリジンの被毒効果と前処理による初期活性変化

クロム含量が増加するにしたがって酸性度も増加し，また触 媒活性も增加することから，反応は何らかの形で酸点と関係し ていると考え，ピリジンを反㐫系に添加してその効果を検討し た。実験は以下の順序に従い結果を Fig. 9 に示す。

（1）窒素気流中 $550^{\circ} \mathrm{C}$ まで反応層を㫒温し，水素に切り 替えて 3 時間還元し，窒素に切り替え $520^{\circ} \mathrm{C} ， 3$ 時間パージを 行ない，そのあとただちに 3 時間反応を行な5。

（2）水素に切り替え 3 時間パージを行ない，そのまま水素 気流中で 3 時間反応を行な5。

（3）公素で 3 時間パージを行ない，その後ただちにイソぺ ンタンに対し 3 vol\% のピリジンを添加して 3 時間反応を行な 5。

（4）窒素で 10 時間パージを行ない，その後イソペンタン のみを試料油として反応を行なう。

（5） $520^{\circ} \mathrm{C}$ において酸素, 水素, 窒素の順でそれぞれ 3 時 


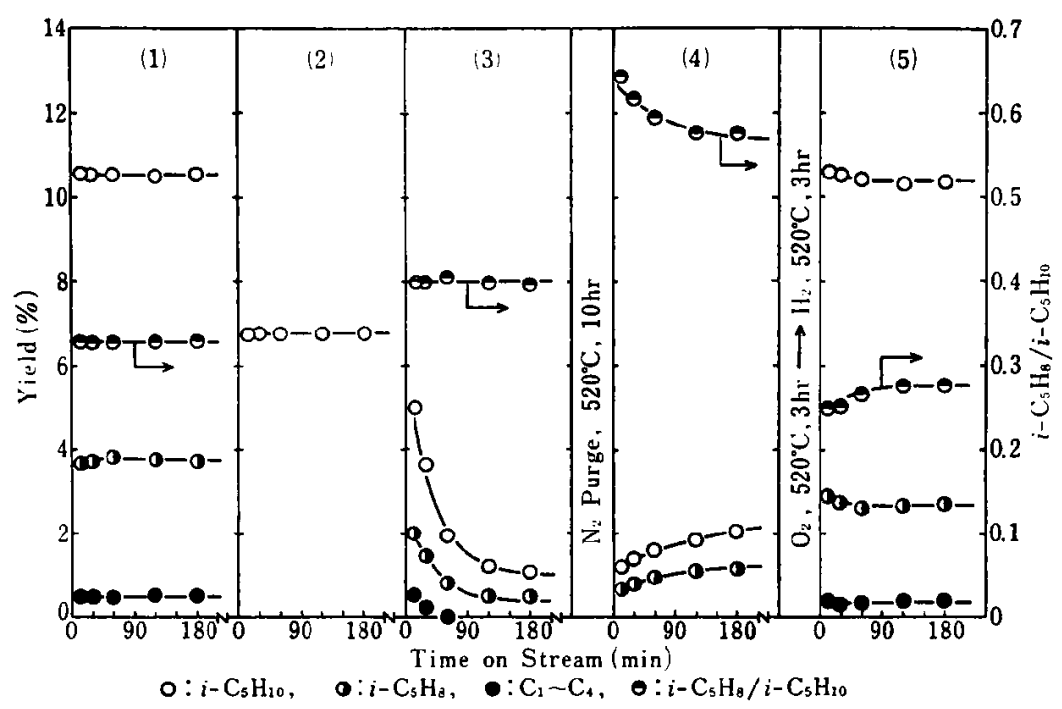

Reaction conditions ; $P_{t}=0.1 \mathrm{~atm}, t=520^{\circ} \mathrm{C}, W / F=34.0 \mathrm{hr} \cdot \mathrm{g}$-cat $/ \mathrm{mol}$-feed, $\mathrm{Cr}_{\mathrm{r}}: 9.18 \mathrm{atom} \%$ Fig. 9 Effect of Diluent and Added Pyridine

間流した後，窒素気流中で 3 時間反応を行なう。 なお（2）以外の反応はすべて窒素気流中で行ない, $t=5300^{\circ} \mathrm{C}$, $W / F=34.2 \mathrm{hr} \cdot \mathrm{g} \cdot \mathrm{cat} / \mathrm{mol} \cdot \mathrm{feed}, P_{i}=0.1 \mathrm{~atm}$ の条件で行なっ た。触媒はクロム含量 9.18 atomg の酸化クロムーアルミナ触 媒を用いた。

(1)〜(5) の実験をみるとこれぞれかなり触媒の活性変化が みられる。(1) では良好な定常活性が保たれ， $i-\mathrm{C}_{5} \mathrm{H}_{8} / i-\mathrm{C}_{5} \mathrm{H}_{10}$ 比もこの反応中は変化しない。しかし水素気流中で反応を行な った (2)の実験では,イソプレンの生成は極度に阻害されかっ 分解生成物の生成は認められない。反応采にピリジンを添加し た（3）の実験になるとその初期活性に変化が認められ反応経過 時間にしたがって活性は低下する。しかしインプレンの生成量 は水素気流中の反応上りも多く, 全体的に $i-\mathrm{C}_{5} \mathrm{H}_{8} / i-\mathrm{C}_{5} \mathrm{H}_{10}$ 比 は（1）の実験よりも增加している。（4）の反応を行なう前に 10 時間窒素でパージを行なったが，活性は大きく回復しなか った。しかし $i-\mathrm{C}_{5} \mathrm{H}_{8} / i-\mathrm{C}_{5} \mathrm{H}_{10}$ 比は急激に上昇した。(4)の反 応が終ってから $520^{\circ} \mathrm{C} て ゙ 3$ 時間ずつ酸素, 水素で処理を行な うと（5）のとおりほぼ（1）の反応の活性に回復することがわ かった。これらのことからピリジンで触媒表面を被毒する上活

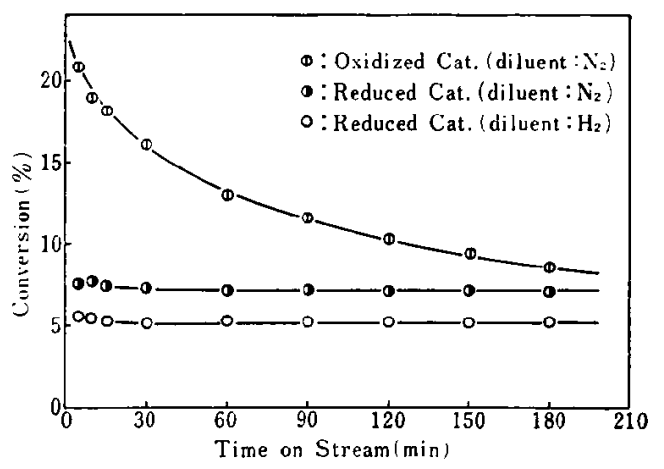

Reaction conditions;

$P_{t}=0.1 \mathrm{~atm}, t=520^{\circ} \mathrm{C}, W / F=34.0 \mathrm{hr} \cdot \mathrm{g}-\mathrm{cat} / \mathrm{mol}-\mathrm{feed}$, $\mathrm{Cr}_{\mathrm{r}}: 9.18$ atom\%

Fig. 10 Initial Activity of Reaction on Oxidized and Reduced $\mathrm{Al}_{2} \mathrm{O}_{3}-\mathrm{Cr}_{2} \mathrm{O}_{3}$
性は大きく減じられる。またイソアミレ ンイソプレンの生成機構はそれぞれ多少 異なるのではないかと思われる。

高温で酸素処理した酸化クロムーアルミ 十触媒は還元状態と異なった举動を示す。 実験に用いた触媒は前と同じクム含量 9.18 atomタ6のものであり，ほかにこの触 媒にクロムに対して原子比で 45 atom\%の リチウムを添加した酸化クロムーアルミナー 酸化りチウム触媒も用いた。酸素処理は触 媒を反応管に充てんし，あらかじめ $550^{\circ} \mathrm{C}$, 5 時間で水素還元した後, 空素でパージを 行ない, さらに $550^{\circ} \mathrm{C} ， 5$ 時間で酸素処理 をしてから再度窒素でパージを行ない反応 を開始した。

酸化クロムーアルミナ触媒では Fig. 10 によると, 反応初期においては酸化処理し た触媒のほうが還元処理した触媒より2倍 以上活性が強く，反応経過時間にしたがって活性が低下する。 この理由は酸化クロムを酸化することにより新しい活性点が形 成し，還元された触媒より活性が強くなるが，徐々に活性が低下 するのは脱水素反応により生成した水素によってクロム自身が 還元され還元状態の触媒の活性に近づくためか、コークが生成 し触媒に沈着し活性が低下するためと考えられる。一方還元さ れた触媒の活性は非常に安定であり，反応開始後 15 分以後は 窒素気流中でも水秦気流中の反応でもほとんど活性変化は認め られない。酸化リチウムを添加した触媒も同様の㑯向を示した が, Table 3 に反态経過時間 60 分後の各種の触媒による反応 生成物分布と酸性度を示した。

酸化リチウムを添加した触媒は無添加の場合と比較して活性 は小さいが，分解および骨格異性化脱水素反応が抑制され脱水 素選択率は 向上する。 $i-\mathrm{C}_{5} \mathrm{H}_{8} / i-\mathrm{C}_{5} \mathrm{H}_{10}$ 比は酸化処理をした触 媒のほうが大きく，水素気流中での反応ではインプレンの生成 が認められない。

触媒の酸性度は酸化された触媒のほうが䢱元された触媒より

Table 3 Effect of Pretreatment (oxidized, reduced) of Catalyst Reaction conditions; $P_{i}=0.125 \mathrm{~atm}, t=520^{\circ} \mathrm{C}, W / F=34.0 \mathrm{hr} \cdot \mathrm{g}$. cat $/ \mathrm{mol}$-feed

\begin{tabular}{|c|c|c|c|c|c|c|}
\hline Pretreatment & \multirow{2}{*}{\multicolumn{2}{|c|}{$\frac{\text { Oxidized* }}{\text { Nitrogen }}$}} & \multicolumn{4}{|c|}{ Reduced** } \\
\hline Diluent & & & \multicolumn{2}{|c|}{ Nitrogen } & \multicolumn{2}{|c|}{ Hydrogen } \\
\hline Catalyst & $\mathrm{Al}-\mathrm{Cr}$ & $\mathrm{Al}-\mathrm{Cr}-\mathbf{L i}$ & $\mid \mathrm{Al}-\mathrm{Cr}$ & $\mathrm{Al}-\mathrm{Cr}-\mathrm{Li}$ & $|\mathrm{Al}-\mathrm{Cr}|$ & Al-Cr-Li \\
\hline $\begin{array}{c}\text { Conversion } \\
(\%)^{* * *}\end{array}$ & 12.84 & 5.85 & 7.14 & 1.66 & 5.22 & 0.98 \\
\hline Yield $(\%)$ & & & $!$ & & & \\
\hline $\mathrm{C}_{1} \sim \mathrm{C}_{4}$ & 0.51 & 0.20 & 0.34 & 0.04 & 0.02 & - \\
\hline$i-\mathrm{C}_{5} \mathrm{H}_{10}$ & 9.79 & 4.50 & 5.74 & 1.52 & 5.15 & 0.98 \\
\hline$i-\mathrm{C}_{5} \mathrm{H}_{8}$ & 2.40 & 1.15 & 1.00 & 0.10 & 一 & - \\
\hline $1-P+2-P$ & 0.14 & - & 0.06 & - & 0.05 & - \\
\hline$\underset{i-\mathrm{C}_{5} \mathrm{H}_{10}}{i-\mathrm{C}_{5} \mathrm{H}_{8} /}$ & 0.25 & 0.26 & 0.17 & 0.07 & 一 & - \\
\hline $\begin{array}{l}\text { Acid Amount } \\
(\mathrm{m} \mathrm{mol} / \mathrm{g})\end{array}$ & 0.89 & 0.68 & 0.42 & 0.30 & 0.42 & 0.30 \\
\hline
\end{tabular}

* Treated with $\mathrm{O}_{2}$ at $550^{\circ} \mathrm{C}, 5 \mathrm{hr}$

** Treated with $\mathrm{H}_{2}$ at $550^{\circ} \mathrm{C}, 5 \mathrm{hr}$

*** Duration $60 \mathrm{~min}$ 
大きく，酸化リチウムを添加すると減少する。高温て酸化され た酸化クロムーアルミナ触媒では, 3 洒と 6 価のクロムの存在が

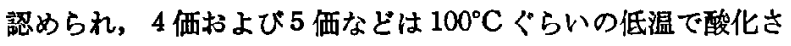
れた場合に存在するといわれている199。いずれにしても 3 価の クロムが最も安定であるから還元状諻の場合は大部分 3 何の形 て酸化クロムは存在するであろら。また酸化状態では 3 価のク 口ムの一部が 6 価に変化していることが予想され，触媒活性と 関係があると考えられる。

\section{5 アルカリ金属, アルカリ土類金属酸化物の添加効果}

クロムに対して原子比で 19.19 atomgののアルカリ金属 $(\mathrm{Li}$, $\mathrm{Na}, \mathrm{K}, \mathrm{Rb}, \mathrm{Cs}$ ) 扰よびアルカリ土類金属 ( $\mathrm{Be}, \mathrm{Mg}, \mathrm{Ca}, \mathrm{Sr}$, Ba）の酸化物を添加した場合のイソ丁ミレン，イソプレン収率 抢よび触媒の酸性度と添加した金属のイオン半径との関倸を Fig. 11, Fig. 12 に示す。なお使用した酸化クロムーアルミナ 触媒はクロム含量 9.18 atom\% である。

図より酸性度はイオン半径には依存せず，アルカリ金属の場 合はナトリウム，カリウム付近に，アルカリ土類金属の場合は マグネシウム，カルシウム付近に最低值があり，イソアミレン 収率も同様の傾向がみられる。またイソプレン収率性酸性度に は対応甘ず，添加した金属酸化物のイオン半径と何らかの関連 があるようであり，アルカリ金属酸化物の場合は特にその傾向 か影著である。その解明は明らかではないが，インアミレンと イソプレンの生成機構は多少異なるのではないかと考えられ る。

\section{6 水素亡イソプレンの阻害作用}

さきに述べよらに反応系中に水素を添加すると，イソプレ ンの生成が極度に阻害され，空素気流中の反応比比較してイン ペンタン消失速度は減少する。Fig. 13 亿示すように同一の反 応温度およびイソペンタン初分圧に扔いて，水素と窒素の混合 比を変化させた場合の効果を検討した。イソペンタン消失速度

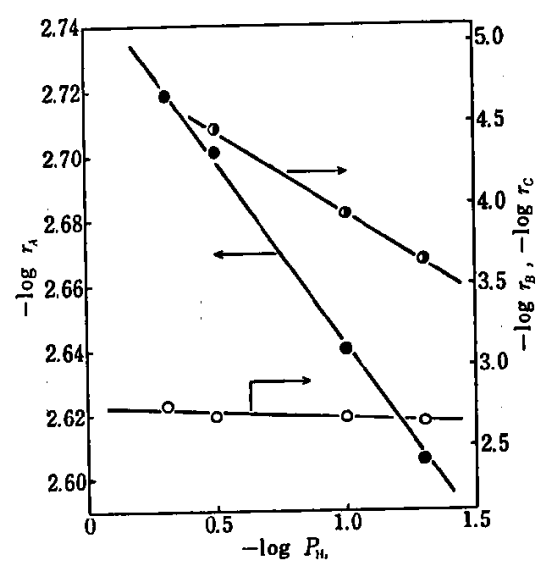

-: Decomposition Rate of Isopentane $\left(r_{A}\right)$, 0 : Formation Rate of Isoamylenes $\left(r_{\mathrm{k}}\right)$. 0 : Formation Rate of Isoprene $\left(r_{\mathrm{c}}\right)$

Reaction Conditions ; $P_{i}=0.1 \mathrm{~atm}, t=500^{\circ} \mathrm{C}$, $W / F=22.7 \mathrm{hr} \cdot \mathrm{g}$-cat $/ \mathrm{mol}$-feed, Cr : 9.18 atom $\%$

Fig. 13 Effect of Hydrogen Partial Pressure $r_{A}$ およびイソアミレン，イソプレン生成速度 $r_{B}, r_{C}$ の対数 と水素分圧 $P_{\mathrm{H}_{2}}$ の対数との関係は良好な直線性を示し, 直線 の傾斜よりおのおのの速度の次数を求めると，水素分圧に関し ては脱水素反応 (イソペンタン消失) はほぼ -0.12 次であり, イソアミレン生成については -0.06 次，イソプレン生成につ いてはー1.0次となった。このことから水素はイソプレンの生 成には非常に影響を与えるが，イソアミレンの生成にはイソプ レンほど䫓著に影響を与えないと言える。すなわちインプレン は非常に反応性に富んだ分子であり，添加あるいは脱水素され た水素により逆反応が促進され見かけ上イソアミレン生成に関 して水素の影響が小さいと言えるのではなかららかと考えられ る。

反応系にイソプレンを添加した場合水素の場合と同様に反応 に阻害作用があり，その結果を Table

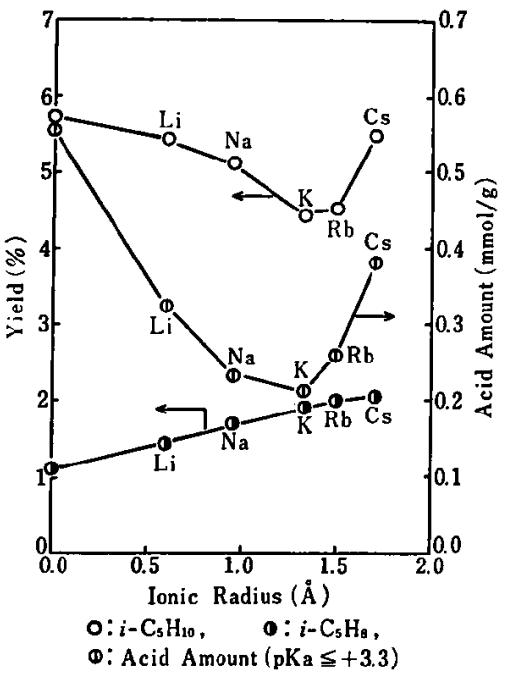

Reaction Conditions;

$P_{i}=0.1 \mathrm{~atm}, t=520^{\circ} \mathrm{C}$

$W / F=22.7 \mathrm{hr} \cdot \mathrm{g}$-cat $/ \mathrm{mol}$-feed, $\mathrm{Cr}_{\boldsymbol{r}}: 9.18$ atom $\%$

Fig. 11 Effect of Added Alkali Metal Oxide to $\mathrm{Al}_{2} \mathrm{O}_{3}-\mathrm{Cr}_{2} \mathrm{O}_{8}$

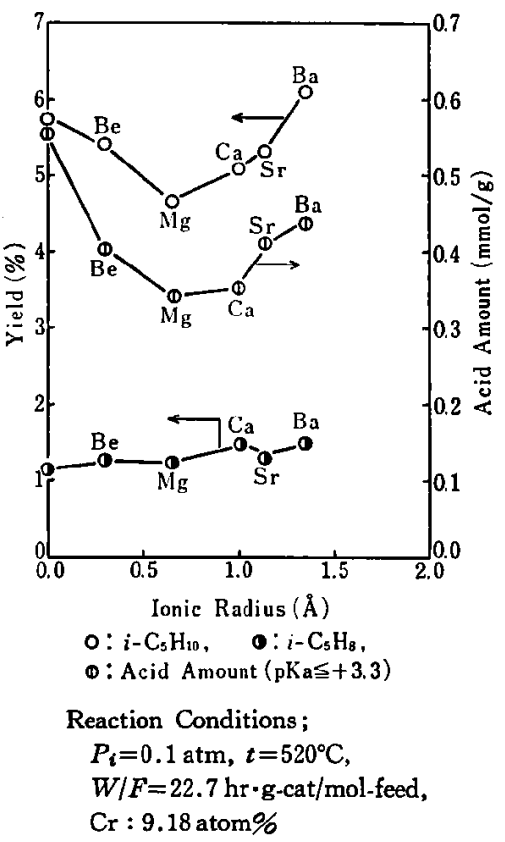

Fig. 12 Effect of Added Alkaline Earth Metal Oxide to $\mathrm{Al}_{8} \mathrm{O}_{8}-\mathrm{Cr}_{2} \mathrm{O}_{4}$
4 に示す。

3.7 イソペンタンとイソアミレン の反応性

イソペンタンと $2 \mathrm{M} 1 \mathrm{~B}$ おび $2 \mathrm{M}$

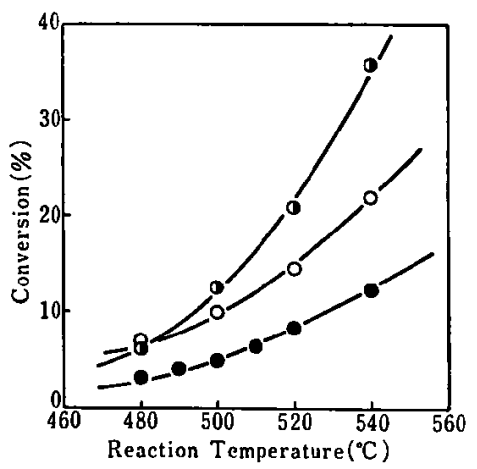

-: Isopentane 0:2M2B O:2M1B

Reaction Conditions;

$P_{i}=0.1 \mathrm{~atm}$,

$W / F=34.0 \mathrm{hr} \cdot \mathrm{g}$-cat $/ \mathrm{mol}$-feed, $\mathrm{Cr}: 9.18$ atom\%

Fig. 14 Reactivity of Isopentane and Isoamylenes on $\mathrm{Al}_{2} \mathrm{O}_{3}-\mathrm{Cr}_{2} \mathrm{O}_{3}$ 
Table 4 Effect of Added Isoprene and Hydrogen

\begin{tabular}{c|c|c|c|c}
\hline $\begin{array}{c}P_{\mathrm{H}_{2}} \\
(\mathrm{~atm})\end{array}$ & $\begin{array}{c}P_{\mathrm{N}_{2}} \\
(\mathrm{~atm})\end{array}$ & $\begin{array}{c}P_{c} \times 10^{\mathrm{a}} \\
(\mathrm{atm})^{*}\end{array}$ & $r_{A} \times 10^{* * *}$ & $\frac{i-\mathrm{C}_{\mathrm{B}} \mathrm{H}_{\mathrm{B}}}{i-\mathrm{C}_{3} \mathrm{H}_{10}}$ \\
\hline 0.00 & 0.90 & 2.43 & 2.93 & 0.33 \\
0.00 & 0.90 & 3.21 & 2.41 & 0.34 \\
0.00 & 0.90 & 4.70 & 1.90 & 0.49 \\
0.00 & 0.90 & 5.15 & 1.74 & 0.52 \\
0.05 & 0.85 & 4.68 & 1.94 & 0.17 \\
0.10 & 0.80 & 4.68 & 1.73 & 0.11 \\
0.30 & 0.60 & 4.68 & 1.55 & 0.03 \\
0.50 & 0.40 & 4.68 & 1.45 & - \\
\hline
\end{tabular}

* Isoprene initial partial pressure

** Decomposition rate of isopentane (mol $/ \mathrm{hr} \cdot \mathrm{g}$-cat)

Reaction conditions; $P_{t}+P_{c}=0.1 \mathrm{~atm}, t=500^{\circ} \mathrm{C}$

$W / F=22.7 \mathrm{hr} \cdot \mathrm{g}$-cat $/ \mathrm{mol}-$ feed,

$\mathrm{Cr}: 9.18$ atom\%

$P_{t}:$ isopentane initial partial pressure

2B をそれぞれ反応原料として，おのおのの炭化水素の酸化ク ロムーアルミナ触媒に対する反応性を険討した。転化率と反応 温度との関保は Fig. 14 によると反応温度が高くなるほど各 種炭化水素の反応率は增加し，2M $1 \mathrm{~B}$ は特にその勃果が顕著 である。また反応温度 $500^{\circ} \mathrm{C}$ 以上における脱水素反応の活性 の序列は以下の上らになり，2M1B が最も反応性が強い。

$$
2 \mathrm{M} 1 \mathrm{~B}>2 \mathrm{M} 2 \mathrm{~B}>\text { イソペンタン }
$$

なお $2 \mathrm{M} 2 \mathrm{~B}$ もイソペンタンより反応性が高く，イソプレン が生成するが，その二重結合の位㯰からそのままイソプレンは 生成できない, しかし $2 \mathrm{M} 1 \mathrm{~B}, 2 \mathrm{M} 2 \mathrm{~B}$ を反店原料とした場 合末反応のモノオレフィンは 3.2 で述べたのと同し平衡混合物 を作ることから反応中䦎体として $2 \mathrm{M} 1 \mathrm{~B}$ か $3 \mathrm{M} 1 \mathrm{~B}$ をへて イソプレンが生成するとして説明できる。

\section{4 まとめ}

酸化クロムーアルミナ系触媒によるインペンタンの脱水素反 态を行ない,次の結果を得た。

(1) 反応温度 $460 \sim 540^{\circ} \mathrm{C}$ ，イソペンタン初分压 $0.08 \sim$ $0.13 \mathrm{~atm}, W / F 11.4 \sim 56.7 \mathrm{hr} \cdot \mathrm{g} \cdot \mathrm{cat} / \mathrm{mol}-\mathrm{feed}$ の条件下で主 反応の脱水素反応生成物は $3 \mathrm{M} 1 \mathrm{~B}, 2 \mathrm{M} 1 \mathrm{~B}, 2 \mathrm{M} 2 \mathrm{~B}$, イソプ レンであり，反応系に水素あるいはイソプレンを添加すると脱 水素反応に阻害作用が認められる。反応事 10\% 以上で副反応 として骨格異性化脱水素反応 (ペンテン類) と分解反応が認め
られる。

(2) 3 M 1 B, 2 M 1 B, 2 M 2 B 同志の組成比は接触時間, 希釈物質，触媒には依存さず一定となり，二重結合の異性化平 衡値に近い值をとる。

(3) 触媒の酸化クロム含量を増加させるとイソペンタンの 脱水秝反応の活性は増加し，その酸性度 $\left(p K_{a} \leqq+3.3\right)$ も增 加する傾向にある。触媒を酸化処理すると初期活性に変化が認 められ，活性は僈元処理した螌媒より強く，イソプレン選択率 が向上する。またピりジンで螌媒表面を被毒すると活性は減し るがイソプレン選択率が変化し，これらのことからイソアミレ ンとイソプレンの生成機構は多少異なると考えられる。

（4）酸化クロムーアルミナ触媒にアルカリ金属，アルカリ 土類金属の酸化物を添加すると, 脱水素選択率に变化が認めら れ，イソプレン収率は添加した金属酸化物のイオン半径と何ら かの相関性があるように考えられる。

(5) $2 \mathrm{M} 1 \mathrm{~B}$ と $2 \mathrm{M} 2 \mathrm{~B}$ を反応原料として脱水素反応を 行ないインペンタンとの反応性を比較するとその序列は以下の ようになる。

$$
2 \mathrm{M} 1 \mathrm{~B}>2 \mathrm{M} 2 \mathrm{~B}>\text { イソペンタン }
$$

$$
\text { 考支献 }
$$

1) たとえば

(a) Grosse, A.V., Ipatieff, V.N., Ind. Eng. Chem.. 32, 268 (1940).

(b) Forni, S.C., Vintani, C., J. Catalysis, 9, 154 (1967).

2) Pines, H., Chen, C.T., J. Am. Chem. Soc., 82, 3562 (1960).

3) Nowak, S., Vieweg, H.G., Erdöl u. Kohle, 19, 618 (1965); 19, 414 (1966).

4) たとえば

(a) Greensfelder, B.S., Fuller, D.L., J. Am. Chem. Soc., 67, 2171 (1945).

（b）吉田, 富田, 冨士原, 鉿村, 石油誌，8，(12)，940 (1965).

5) Di Giacomo, A.A., Maerker, J.B., Schall, J.W., Chem. Eng. Prog., 57, 5, 35 (1961).

6) Steligov, O.D. et al., Neftekhimiya, 5, 10 (1965): 8, 166 (1968).

7) Usov, Yu. N. et al., ibid., 7, 341 (1967).

8) Honaday, G.F., Petrol. Engr., 26, 11, C-7 (1954).

9) JIS M 8262 (1969).

10）日本化学会螎，“実駼化学誨座-続”V Vol，9，141 (1965) 丸善.

11) API Research Project 44, "Selected Values of Properties of Hydrocarbons and Related Compounds" (1970).

12）石井, 瀬川, 石油学会第13回研究発表会要旨集, 104 (1970).

13) Burzyk, J. et al., J. Catalysis, 2, 161 (1963). 